\title{
Influence of Employee Discipline, Compensation and Employee Load on Employee Performance in PT. Tozy Sentosa in Surabaya
}

\author{
Indah Kusasih and Hermien Tridayanti \\ Faculty of Economics, management of Narotama University, Surabaya \\ arindah0505@gmail.com, hermien.tridayanti@narotama.ac.id
}

\begin{abstract}
This study aims to determine the effect of simultaneous and partial compensation and workload discipline on the performance of employees of PT. Tozy Santosa Surabaya. This research is a quantitative study. Population and sample based on the distribution of questionnaires to the performance of the employees of PT. Tozy Santosa Surabaya was taken as many as 40 respondents. Data collection techniques used interviews, observations and questionnaires. Data analysis used was reliability test, validity test, classic assumption test and multiple linear analysis test. The results of the study were simultaneous and partial discipline, compensation and workload significant effect on the performance of employees of PT. Tozy SantosaSurabaya because of the significance of $<0.005$.
\end{abstract}

Keywords:

Discipline, Compensation, workload, Employee Performance.

\section{Introduction}

The retail business in Indonesia is experiencing quite good development. This shows that the organization is increasingly responsive to changing circumstances in entering the era of globalization. Rapid changes and increasingly fierce competition make it possible for any organization that wants to exist to be able to maintain high trust from the community. In order to achieve a balance in building and maintaining the business, the company must be able to manage its human resources optimally so that it has a positive impact on the company. Therefore, companies must have a way of managing the human resources they have. Human resource management in a company can be done, among others, by providing incentives and motivation to employees which in turn will affect employee performance results so that company goals can be achieved, both in the form of short, medium and long term goals.

The most important asset that must be owned by an organization or company in management is human labor. According to Yuli (2005: 15) in Bintoro and Daryanto (2017: 16) human resources are activities that regulate the way labor is procured, conducts development, provides compensation, maintenance, and separation of labor through management processes in order to achieve organizational goals. Human resources are one of the determinants of an organization that can run well or not. Human resources must be further improved in optimizing work results. Many advantages of the organization or company, will not be able to maximize productivity and profits without the existence of a community of employees who are skilled, competent and highly dedicated to the organization or company. To achieve this the company creates a situation that can improve employee performance.

Improved employee performance will bring progress for the organization to be able to survive in an unstable work environment competition. Thus, the success of an organization depends on the quality of the performance of human resources in it. According to Bernandidan Russell (2001) in Bintoro and Daryanto (2017: 105) performance is a record that results from the function of a particular job or activity during a certain period of time. The performance is not only in the form of individual work but also the work of the group will be needed in the company for the survival and continuity of the company. A good organization is an organization that tries to improve the ability of its human resources, because it is a key factor to improve employee performance. Improved performance for employees has a very important meaning, especially in efforts to make improvements to achieve organizational goals. Thus the important role of resources humans are fully realized in the steps of achieving goals and improving the quality of employees.

Another factor that also determines employee performance is compensation. Providing a compensation system is expected to create a reciprocal relationship between employees and the company, employees get justice in 


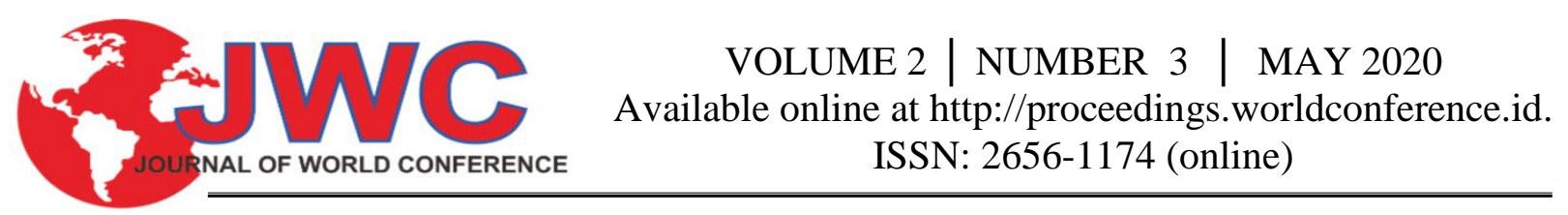

Compensation is something that is considered as something comparable. Based on the income of the experts, it can be concluded that compensation is an interaction between employees and organizations in the form of reciprocity from services or labor expended by employees and awards from the organization in the form of wages or other facilities. Components of the overall salary program are generally grouped into compensation direct financial, indirect and non financial.

1. Direct financial compensation in the form of principal payments (salaries and wages), achievement fees, incentive payments (bonuses, commissions, profit / profit sharing and stock options) and deferred payments (savings and annuity payment programs).

2. Indirect financial compensation in the form of protection programs (health insurance, life insurance, pensions, labor insurance), pay outside working hours (holidays, holidays, annual leave and maternity leave), and facilities such as vehicles, office space and parking lot.

3. Non-financial compensation, in the form of work (interesting tasks, challenges, responsibilities, recognition and a sense of achievement). Work environment (sound policy, healthy supervision, competent supervision, pleasant relatives, comfortable work environment).

\subsection{Workload}

Gawron (2008: 87) defines workload as follows "Workload has been defined as a set of task demands, as effort, and as activity or accounting," which means that workload has been defined as a set of task demands, as an effort, and as an activity or achievements. Schultz and Schultz (2006: 366) states the workload as follows "Work overload is too much to perform in the time available or work that is toodiffic for the employee to perform", which means that the workload is too much doing work at the time available or doing work that is too difficult for employees According to Kirmeyer \& Dougherty (1988), excessive workload will affect employee job satisfaction and employee performance. This can have an impact on employee loyalty. Bullger (2001: 184) states that "Mental workload is a way of describing the mental stress and the strain of being busy at work. Excessive 'mental work load' often leads to mistakes, misunderstandings, omissions and other errors, these include: remembering to dothings and formulation and implementation of plans of actions ", which means that mental workload is a way of describing mental stress and tension during busy work. Many mental workloads often lead to mistakes, misunderstandings, omissions and other mistakes, for example remembering to do something and compiling and implementing action plans. Robbins (2007: 90) states that positive and negative workloads are a matter of perception. Perception is defined as a process in which individuals organize and interpret their sense impressions to give meaning to their environment (Robbins, 2007: 160). Workload consists of three dimensions or factors, namely time load, namely the amount of time available in carrying out a job, mental load (mental effort load), namely the amount of mental effort in carrying out a job, and psychological stress load which indicates the level of work risk, confusion and frustration (Reidet al, 1981)

\subsection{Performance}

According to Mangkunegara (2000: 67) in Mangkunegara (2014: 9) states that "Employee performance (work performance) is the work of quality and quantity achieved by an employee in carrying out their duties in accordance with the responsibilities given to him", then perfected by Mangkunegara (2014: 9) concluded that "Human Resource Performance or Work Achievement is the work or output (quality) both quality and quantity achieved by human resources one time period in carrying out their work duties in accordance with the responsibilities given. According to Robins (2006) in Bintoro and Daryanto (2017: 105), performance is the amount of effort expended by individuals in their work. According to Bernadidan Russell (2001) Bintoro and Daryanto (2017: 105) performance is a record that results from the function of a particular job or activities over a certain period of time. According Sinambela, et al (2012) Bintoro and Daryanto (2017: 105) suggest that employee performance is defined as the ability of employees to perform certain skills. 


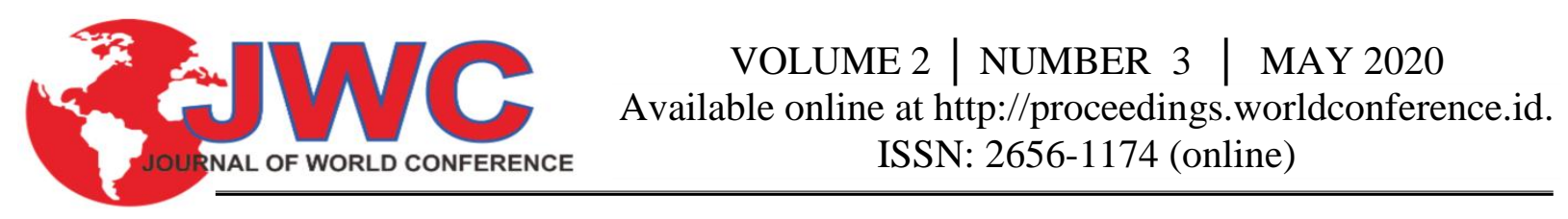

\subsection{Framework}

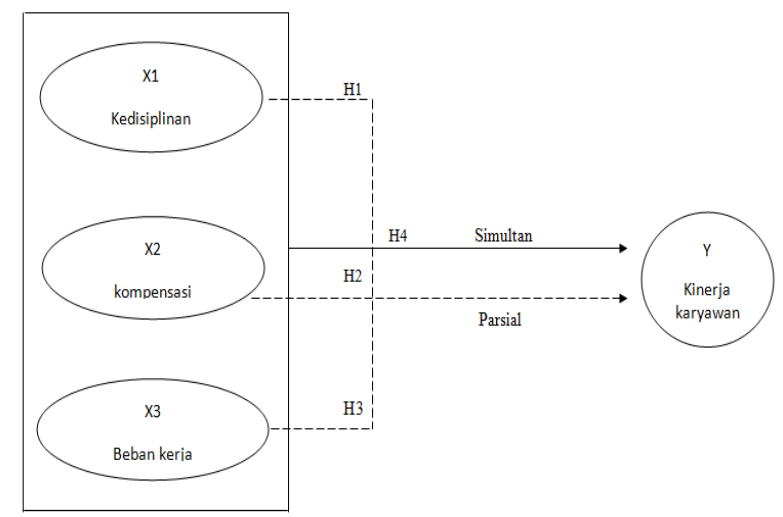

Figure 2.1 Research Conceptual Framework

\subsection{Research Hypothesis}

Based on the explanation above, the following research hypotheses can be proposed:

H1: Employee discipline has a partially significant effect on the performance of employees of PT. Tozy Sentosa Surabaya.

H2: Compensation has a partially significant effect on the performance of PT. Tozy Sentosa Surabaya employees.

H3: Workload has a partially significant effect on the performance of PT. Tozy Sentosa Surabaya's employees.

H4: discipline, compensation and workload have a significant effect simultaneously on the performance of PT. Tozy Sentosa Surabaya employees.

\section{Methodology}

\subsection{Population and Sample}

According to Sugiyono (2016: 80) population is a generalization area consisting of objects or subjects that have certain qualities and characteristics determined by researchers to be studied and then drawn conclusions. The population in this study are employees of PT. Tozy Sentosa Surabaya, amounting to 40 resource

\subsection{Data analysis method}

The analytical method used is the quantitative method by operationalizing the disciplinary variable (X1), compensation (X2) workload (X3). employee performance (Y)

The stages include Validity and Reliability Test, Multiple Linear Regression Analysis $\mathrm{f}$ test and $\mathrm{t}$ test, Determination Coefficient Test (R2), classic assumption test including Multicollinearity test, Heteroskeasticity test and Normality test

The coefficient of determination with the following equation:

\subsection{Regression Equation}

$\mathrm{Y}=\mathrm{a}+\mathrm{b} 1 \mathrm{X} 1+\mathrm{b} 2 \mathrm{X} 2+\mathrm{b} 3 \mathrm{X} 3$

Information :

$\mathrm{Y}=$ Employee performance

$\mathrm{a}=$ Constant Value

b1, b2, b3 = Variable Coefficient

$\mathrm{X} 1=$ Discipline

$\mathrm{X} 2$ = compensation

$\mathrm{X} 3=$ Workload

$\mathrm{e}=$ Error (error term)

\section{Result and Discussion}

\subsection{Description of Research Results}

Respondents in this study were employees Respondents in this study were employees of PT. Tozy Santosa Surabaya, amounting to 40 people. The collection of primary data is done by giving questionnaires to the employees of PT. Tozy Santosa Surabaya by spreading. Characteristics of respondents based on gender, marital status, age, last education. Respondent characteristics are presented in the following Table 4.1: 


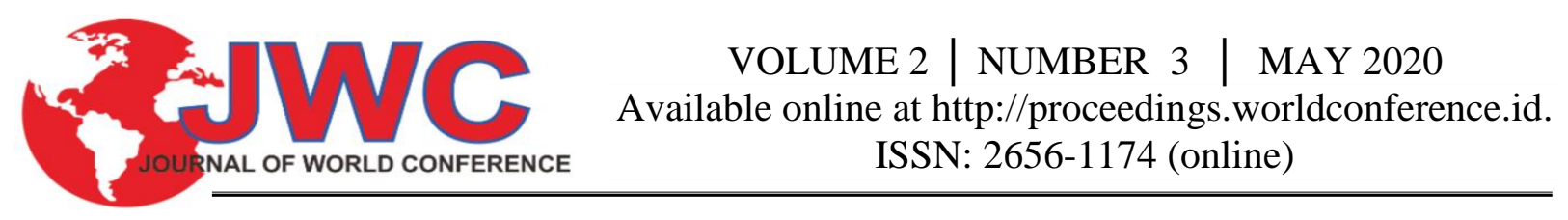

Table 4.1 Samples and Returns Questionnaire

\begin{tabular}{|l|c|c|c|}
\hline \multicolumn{1}{|c|}{ Description } & Amount & Percentage & Amount \\
\hline Total Distribution of Questionnaires & 40 & $100 \%$ & $100 \%$ \\
\hline Total Questionnaire Returns & 40 & 40 & $100 \%$ \\
\hline Questionnaire Not Returned & 0 & 0 & $0 \%$ \\
\hline Processed Questionnaire & 40 & 40 & $100 \%$ \\
\hline
\end{tabular}

Source: Primary data processed, 2019

Based on Table 4.1 above shows that 40 questionnaires were distributed, 40 returned questionnaires and 40 questionnaires that could be processed and analyzed

\subsection{Characteristics of Respondents by Gender}

Based on the results of the questionnaire distribution of 40 respondents obtained the characteristics of respondents by sex can be seen in the table below:

Table 4.2: Characteristics of Respondents by Gender

Gender
\begin{tabular}{|c|r|r|r|r|}
\hline & Frequency & Percent & Valid Percent & Cumulative Percent \\
\hline Valid Men & 8 & 20,0 & 20,0 & 20,0 \\
Women & 32 & 80,0 & 80,0 & 100,0 \\
Total & 40 & 100,0 & 100,0 & \\
\hline
\end{tabular}

Source: Primary data processed, 2019

Based on table 4.2 it can be seen that the highest number of respondents by sex is women with a percentage of $80.0 \%$ or (32 people) while the percentage of male respondents is $20.0 \%$ or (8 people).

Table 4.3: Characteristics of Respondents by Job

\begin{tabular}{|l|r|r|r|r|}
\hline & Fob \\
\hline & Frequency & Percent & Valid Percent & Cumulative Percent \\
\hline Valid Swasta & 40 & 100,0 & 100,0 & 100,0 \\
\hline
\end{tabular}

Based on Table 4.3, it is known that respondents with Private jobs are more dominant Overall with a percentage of $100.0 \%$ or (40 people), then there are no student respondents, civil servants, entrepreneurs with a percentage of $0 \%$ or $(0)$.

\subsection{Characteristics of Respondents by Age}

Based on the results of the distribution of 40 respondents questionnaire obtained respondent characteristics based on age can be seen in the table below:

Table 4.4 : Characteristics of Respondents by Age

Age
\begin{tabular}{|r|r|r|r|r|}
\hline & Frequency & Percent & Valid Percent & Cumulative Percent \\
\hline Valid 17-22 & 7 & 17,5 & 17,5 & 17,5 \\
$23-28$ & 22 & 55,0 & 55,0 & 72,5 \\
$29-33$ & 11 & 27,5 & 27,5 & 100,0 \\
Total & 40 & 100,0 & 100,0 & \\
\hline
\end{tabular}

Source: SPSS Output Data (2019) 


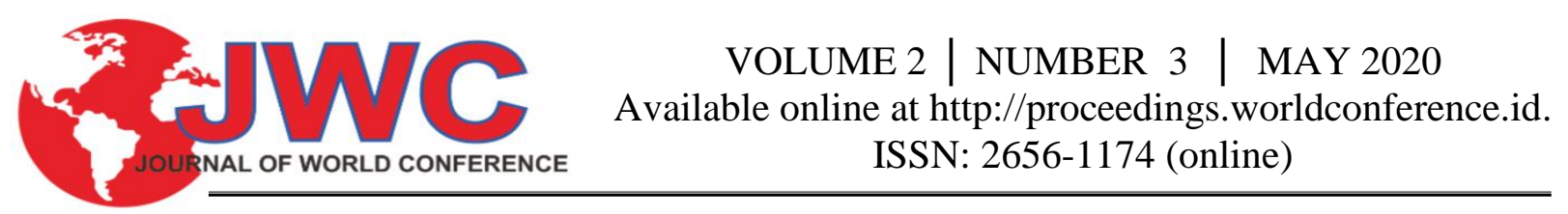

Based on table 4.4 it is known that respondents with ages $23-38$ more with a percentage of $55.0 \%$ or $(22$ people), then respondents with ages $17-22$ as many as $17.5 \%$ or (7 people), aged $29-33$ as many as $27.5 \%$ or (11 people) and age $>35$ as many as none with a percentage of $0 \%$ or $(0)$.

\subsection{Characteristics of Repondents Based on Education}

Based on the results of the distribution of 70 respondents the questionnaire obtained characteristics of respondents based on education can be seen in the table below:

Table 4.5 :Characteristics of Respondents by Education

\section{Education}

\begin{tabular}{|l|r|r|r|r|}
\hline & Frequency & Percent & Valid Percent & Cumulative Percent \\
\hline Valid High School & 39 & 97,5 & 97,5 & 97,5 \\
Bachelor & 1 & 2,5 & 2,5 & 100,0 \\
Total & 40 & 100,0 & 100,0 & \\
\hline \multicolumn{5}{c}{ Source: SPSS Output Data (2019) }
\end{tabular}

Based on table 4.5 it is known that respondents with high school / equivalent education more with a percentage of $97.5 \%$ or (39 people), and respondents with a Bachelor's education as much as $2.5 \%$ or (1 person).

\subsection{Variable Description}

To facilitate the assessment of the results of the distribution of questionnaires in this study by categorizing the average responses of respondents to each of the indicators of questions that have been raised. To determine the category value for each variable in the study, the formula for finding class intervals is as follows:

$$
=\frac{5-1}{5}=0,8
$$

Values 1 and 5 come from the highest and lowest scores on the questionnaire. A summary of the results of the category provisions that apply to the variables observed in this study are as follows:

Interval Kelas $=\frac{\text { Nilai tertinggi }- \text { Nilai terendah }}{\text { Jumlah kelas }}$

Table 4.6 Rating Category

\begin{tabular}{|l|l|l|}
\hline \multicolumn{1}{|c|}{ Interval } & \multicolumn{1}{|c|}{ Category } & Value \\
\hline $4,20<\mathrm{a} \leq 5,00$ & Strongly agree & 5 \\
\hline $3,40<\mathrm{a} \leq 4,20$ & Agree & 4 \\
\hline $2,60<\mathrm{a} \leq 3,40$ & Ordinary & 3 \\
\hline $1,80<\mathrm{a} \leq 2,60$ & Disagree & 2 \\
\hline $1,00<\mathrm{a} \leq 1,80$ & Strongly Disagree & 1 \\
\hline
\end{tabular}

Source: Primary data processed, 2019

The following is a calculation with the average value and overall category for each variable.

\section{Description of Disciplinary Variables $\left(\mathbf{X}_{1}\right)$}

Table 4.7 Respondents Response Regarding Discipline (X1)

\begin{tabular}{|l|l|l|l|}
\hline No & \multicolumn{1}{|c|}{ Statement } & Mean & \multicolumn{1}{c|}{ Information } \\
\hline 1 & The size of the unprofessional compensation for employees & 3,62 & Agree \\
\hline 2 & The lack of example from the leadership to discipline is reduced & 3,81 & Agree \\
\hline 3 & The applicable rules refer to many SOPs so that discipline is abandoned & 4,34 & Strongly Agree \\
\hline 4 & Lack of leadership decisiveness in determining action & 4,25 & Agree \\
\hline \multicolumn{2}{|c|}{ Average } & $\mathbf{4 , 0 0}$ & Agree \\
\hline
\end{tabular}

Source: Primary data processed, 2019 


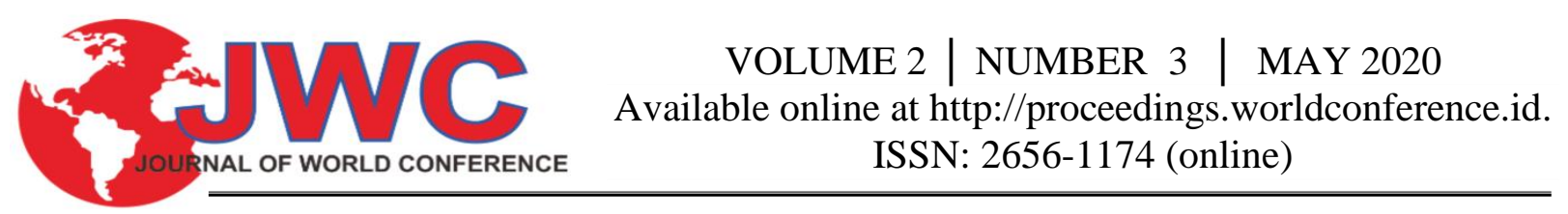

Based on the data of respondents' responses in table 4.7 it can be seen that the average respondent's answers to the first, second, and fourth statements are at intervals of $3.40<\mathrm{a} \leq 4.20$. This shows that the respondent agreed with the statement submitted regarding the disciplinary variable (X1). S While the average respondent's answer to the third statement is at an interval of $4.20<\mathrm{a} \leq 5.00$. This shows that the respondents strongly agree with the statements submitted regarding the disciplinary variable (X1).

\section{Description of compensation variable (X2)}

Table 4.8 Respondents' Responses Regarding Compensation (X2)

\begin{tabular}{|l|l|l|l|}
\hline No & Statement & Mean & Information \\
\hline 1 & The social security obtained is quite appropriate for employees & 3,92 & Degree \\
\hline 2 & $\begin{array}{l}\text { Achievement Bonuses in the form of money given to employees are already } \\
\text { professional }\end{array}$ & 3,72 & Degree \\
\hline 3 & Giving awards to employees who meet sales targets & 4,12 & $\begin{array}{l}\text { Strongly } \\
\text { Degree }\end{array}$ \\
\hline 4 & $\begin{array}{l}\text { Job promotions for employees who have worked more than one year to the next } \\
\text { position }\end{array}$ & 3,24 & Degree \\
\hline Average & $\mathbf{3 , 7 5}$ & Degree \\
\hline
\end{tabular}

Source: Primary data processed, 2019

Based on the data of respondents' responses in table 4.8 it can be seen that the average respondent's answers to the first, second, third and fourth statements are at intervals of $3.40<\mathrm{a} \leq 4.20$. This shows that the respondent agreed with the statement submitted regarding the compensation variable (X2).

\section{Workload Variable Description (X3)}

Table 4.9 Respondents Response Workload (X3)

\begin{tabular}{|l|l|l|l|}
\hline No & Statement & Mean & Information \\
\hline 1 & The less professional work assignments given by the leadership & 3,32 & Degree \\
\hline 2 & Very boring workplace environment & 3,45 & Degree \\
\hline 3 & Internal organization in which disputes occur & 3,52 & Degree \\
\hline 4 & Age is a factor of workload in the company environment & 4,25 & Strongly Degree \\
\hline Average & $\mathbf{3 , 6 3}$ & Degree \\
\hline
\end{tabular}

Based on the data of respondents' responses in table 4.9 it can be seen that the average respondent's answers to the first, second and third and fourth statements are at an interval of $3.40<\mathrm{a} \leq 4.20$. This shows that the respondents agreed with the statement submitted regarding the Customer Workload (X3) variable.

\section{Employee Performance Variable Description Y}

Table 4.10 Respondents' Responses Regarding Employee Performance (Y)

\begin{tabular}{|l|l|l|l|}
\hline No & Statement & Mean & Information \\
\hline 1 & The work quantity obtained by the employee has fulfilled the achievement & 3,32 & Degree \\
\hline 2 & The quality of professional work carried out by employees & 3,45 & Degree \\
\hline 3 & Timeliness of employee's work hours and absence according to company rules & 4,42 & Strongly Degree \\
\hline 4 & Work effectiveness meets the company rules & 3,21 & Degree \\
\hline 5 & Independence from employees who already reflect professional work & 4,19 & Setuju \\
\hline Average & $\mathbf{3 , 7 1}$ & Degree \\
\hline
\end{tabular}

Source: Primary data processed, 2019

Based on the data of respondents' responses in table 4.10 it can be seen that the average respondent's answers to the first, second, fourth and fifth statements are at an interval of $3.40<\mathrm{a} \leq 4.20$. This shows that the respondents agreed with the statement submitted regarding employee performance variables (Y).

While the average respondent's answer to the third statement is at an interval of $4.20<\mathrm{a} \leq 5.00$. This shows that the respondents strongly agree with the statements submitted regarding employee performance variables (Y). 


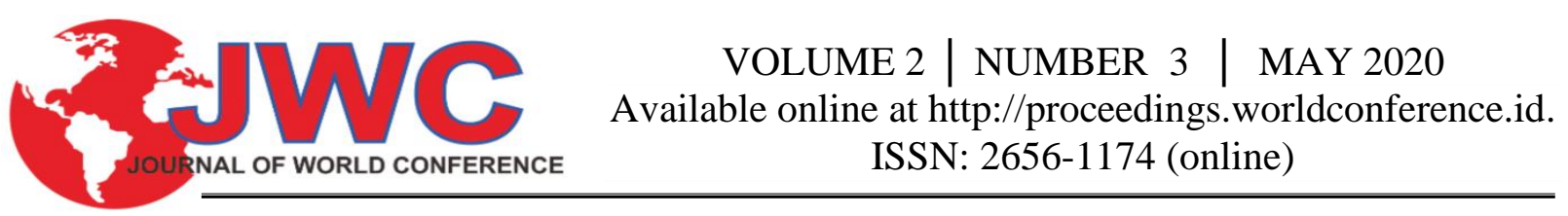

\subsection{Data Analysis and Hypothesis Testing Reliability and Validity Test}

Data processing used in this study uses SPSS Version 18.0, with the type of data processed by being transformed from an ordinal form into an interval using the Method of Successive Interval. to facilitate data processing in order to explain the results of respondents from the variables to be examined.

\section{Reliability Test}

Reliability test is a tool to measure a questionnaire which is an indicator of the variables of a questionnaire, declared reliable / reliable if someone's answer to a question is consistent or stable from time to time (Ghozali, 2013). The reliability test is carried out with the help of SPSS which is a facility to measure reliability with the alpha cronbach $(\alpha)$ statistical test of a variable said to be reliable if it has an alpha cronbach $>0.60$. The reliability test results in this study can be seen in table 4.11 as follows:

\begin{tabular}{|c|c|}
\hline Cronbach's Alpha & $\mathrm{N}$ of Items \\
\hline .747 & 21 \\
\hline
\end{tabular}

Source: SPSS Output Data (2019)

Can be seen from table 4.11 above, this research data has a Cronbach's alpha of 0.747 and is above 0.60 , then this research data can be stated reliable and trustworthy.

\section{Validity Test}

To test the validity of the instrument the product moment correlation formula is used with the test criteria if the correlation between items with a total score of more than 0.3 then the instrument is declared valid, or vice versa if the correlation between items with a total score of less than 0.3 then the instrument is declared invalid . (Arikunto, 2008: 72).

Based on the analysis that has been done, the validity test results can be shown as follows:

\begin{tabular}{|l|l|l|l|l|}
\hline \multicolumn{1}{|c}{ Table 4.12 Results of Validity Test X1 } \\
\hline Variabel & Indikator & $\begin{array}{l}\text { Correla } \\
\text { tion }\end{array}$ & Minimum Limit & $\begin{array}{l}\text { Inform } \\
\text { ation }\end{array}$ \\
\hline X1 Discipl & X1.1 & 0,807 & 0,3 & Valid \\
Ine & X1.2 & 0,894 & 0,3 & Valid \\
& X1.4 & 0,838 & 0,3 & Valid \\
\end{tabular}

Source: SPSS Output Data (2019)

From table 4.12 the Validity test of the Discipline variable (X1) above shows the number of person correlation> 0.3 then with these results, all the variables above are said to be valid because the results are>0.3.

Table 4.13 Results of Validity Test X2

\begin{tabular}{|l|l|l|l|l|}
\hline Variabel & Indikator & $\begin{array}{l}\text { Correla } \\
\text { tion }\end{array}$ & Minimum Limit & $\begin{array}{l}\text { Inform } \\
\text { ation }\end{array}$ \\
\hline \multirow{3}{*}{ X2 Compes } & X2.1 & 0,424 & 0,3 & Valid \\
Ation & X2.2 & 0,800 & 0,3 & Valid \\
& X2.3 & 0,697 & 0,3 & Valid \\
& X2.4 & 0,665 & 0,3 & Valid \\
\hline
\end{tabular}

Source: SPSS Output Data (2019)

From table 4.13 the Validity test of the Compensation variable (X2) above shows the number of person correlation> 0.3 then with these results, all the variables above are said to be valid because the results are>0.3. 
Table 4.14 Results of Validity Test X3

\begin{tabular}{|l|l|l|l|l|}
\hline Variable & Indicator & $\begin{array}{l}\text { Correl } \\
\text { ation }\end{array}$ & Minimum Limit & $\begin{array}{l}\text { Inform } \\
\text { Ation }\end{array}$ \\
\hline X3 work & X3.1 & 0,405 & 0,3 & Valid \\
Load & X3.3 & 0,813 & 0,3 & Valid \\
& X3.4 & 0,723 & 0,3 & Valid \\
\hline
\end{tabular}

Source: SPSS Output Data (2019)

From table 4.14 variable validity test Workload (X3) above shows the number of person correlation> 0.3 then with these results, all the variables above are said to be valid because the results> 0.3 .

Table 4.15 Results of Validity Test Y

\begin{tabular}{|l|l|l|l|l|}
\hline Variable & Indicator & $\begin{array}{l}\text { Correl } \\
\text { ation }\end{array}$ & Minimum Limit & $\begin{array}{l}\text { Inform } \\
\text { ation }\end{array}$ \\
\hline & Y.1 & 0,748 & 0,3 & Valid \\
Y the perform & Y.2 & 0,714 & 0,3 & Valid \\
ance & Y.3 & 0,776 & 0,3 & Valid \\
& Y.4 & 0,683 & 0,3 & Valid \\
& Y.5 & 0,487 & 0,3 & Valid \\
\hline
\end{tabular}

Source: SPSS Output Data (2019)

From table 4.15 the Validity test of the Performance variable $(\mathrm{Y})$ above shows the number of person correlation $>0.3$ then with these results, all the variables above are said to be valid because the results are>0.3.

\subsection{Normal Distribution Test}

The Normal Distribution Test is a test carried out to conduct prerequisites for data analysis. This test is done before the data is managed based on a model that will be submitted. Data normality test aims to analyze data in one variable that will be used in a study. The normality test used is the Kolmogorov-Smirnov test. The data will be said to be normal, if the significant value is greater than $0.05(\mathrm{p}>0.05)$. Conversely, if the significant value is less than 0.05 at ( $\mathrm{p}<0.05$ ), then it is said to be abnormal (Sugiyono, 2013).

Table 4.16 Normal Distribution Test Results

One-Sample Kolmogorov-Smirnov Test

\begin{tabular}{|ll|r|}
\hline & & Unstandardiized Residual \\
\hline $\mathrm{N}$ & & 40 \\
Normal Parameters $^{\mathrm{a}}$ & Mean & .0000000 \\
& Std. Deviation & 4,07246116 \\
& & .082 \\
Most Extreme Diifferences & Absolute & .082 \\
& Positive & -.066 \\
& Negative & .517 \\
Kolmogorov-Smirnov Z & & .952 \\
Asymp. Sig. (2-tailed) & & \\
\hline
\end{tabular}

a. Test distribution is Normal.

Source: SPSS Output Data (2019)

From table 4.16 above shows the Asymp normal distribution test. Sig. (2-tailed), 952 because of the value of Asymp. Sig. (2-tailed) more than $>0.05$ then the results are normal. 


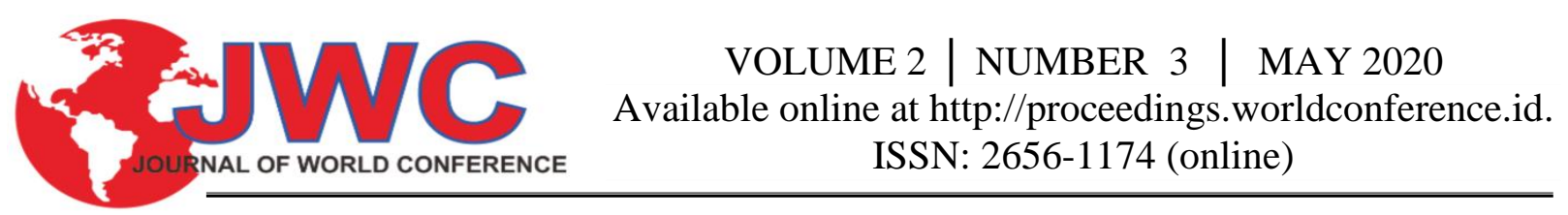

\subsection{Equation of Multiple Linear Regression}

This study uses a linear regression analysis model to prove the research hypothesis. This analysis will use input based on data obtained from the questionnaire. The statistical calculation in the multiple linear regression analysis used in this study is to use SPSS 18 program. The summary of data processing using the SPSS program in this study is shown in table 4.17 as follows.

Table 4.17 Multiple Linear Regression Test Results

\section{Coefficients $^{\mathrm{a}}$}

\begin{tabular}{|l|r|r|l|l|l|r|}
\hline & \multicolumn{3}{|l|}{ Unstandardized Coefficients } & Standardized Coefficients & & \\
\cline { 2 - 5 } Model & B & Std. Error & Beta & \multicolumn{1}{c|}{ S } & Sig. \\
\hline 1 (Constant) & .628 & 1.087 & & .578 & .565 \\
Total_X1 & .177 & .054 & & .262 & 3.278 & .002 \\
Total_X2 & .217 & .092 & .247 & 2,353 & .022 \\
Total_X3 & .439 & .097 & .466 & 4.547 & .000 \\
\hline
\end{tabular}

a. Dependent Variable: Total_Y

Source: SPSS Output Data (2019)

$\mathrm{Y}=\mathrm{a}+\mathrm{b} 1 \mathrm{X} 1+\mathrm{b} 2 \mathrm{X} 2+\mathrm{b} 3 \mathrm{X} 3+\mathrm{e}$

$\mathrm{Y}=0,628+0.177 \mathrm{X} 1+0.217 \mathrm{X} 2+0,439 \mathrm{X} 3+\mathrm{e}$

1. Constants

Obtained $\mathrm{Y}$ value of .628 means the value of employee performance $(\mathrm{Y})$ of 0.628 units if it is assumed that Compensation, Discipline and Workload, the employee's performance $(\mathrm{Y})$ is 0 means that if the value of the independent variable is 0 then the dependent or dependent variable will be .628 .

2. Compensation coefficient (X1)

Compensation Coefficient (X1) of .177, if Compensation increases (X1) it will improve the Performance of Employees of PT. Tozy Sentosa Surabaya (Y) of .177 units. Assuming the value of Discipline (X2) and Load (X3) is equal to zero.

3. Discipline Coefficient (X2)

The coefficient value of Discipline (X2) is .217, if the employees of PT> Tozy Sentosa Surabaya increase Discipline (X2), it will increase employee performance (Y) by .217 units. Assuming the value of Compensation (X1) and workload (X3) is equal to zero

4. Workload Coefficient Value (X3)

Workload coefficient value (X3) of .439, if the employees of PT. Tozy Sentosa Surabaya increasing workload (X3) will increase the performance of PT. Tozy Sentosa Surabaya (Y) employees by .439 units. Assuming the value of Compensation (X1) and Discipline (X2) is equal to zero.

Table 4.18 Calculation Results for the Determination Coefficient (R2)

Summary Model

\begin{tabular}{|l|l|r|r|r|r|}
\hline Model & R & R Square & Adjusted R Square & Std. Error of the Estimate & Durbin-Watson \\
\hline 1 &, $941^{\mathrm{a}}$ &, 885 &, 868 & 1,49286 & 2,250 \\
\hline
\end{tabular}

a. Predictors: (Constant), Total_X3, Total_X1, Total_X2

b. Dependent Variable: Total_Y

Source: SPSS Output Data (2019)

Based on table 4.18 above, the coefficient value (R) shows the significance of the influence of the independent variables of discipline (X1), compensation (X2), and workload (X3) on the dependent variable of employee performance (Y), the magnitude of the coefficient value is, 941. This means that the independent variables of discipline (X1), compensation (X2), and workload (X3) have a strong or close influence on employee performance dependent variables $(\mathrm{Y})$.

The coefficient of determination or Adjust $R$ Square (" $\left.R^{R " 2 "}\right)$ is obtained as large as 868 , which means that the contribution of independent variables does not affect the dependent variables of discipline (X1), compensation $(\mathrm{X} 2)$, and workload (X3) on employee performance variables ( Y) of $86.8 \%$. While the remaining $13.2 \%$ is influenced by variables not examined in this study. 


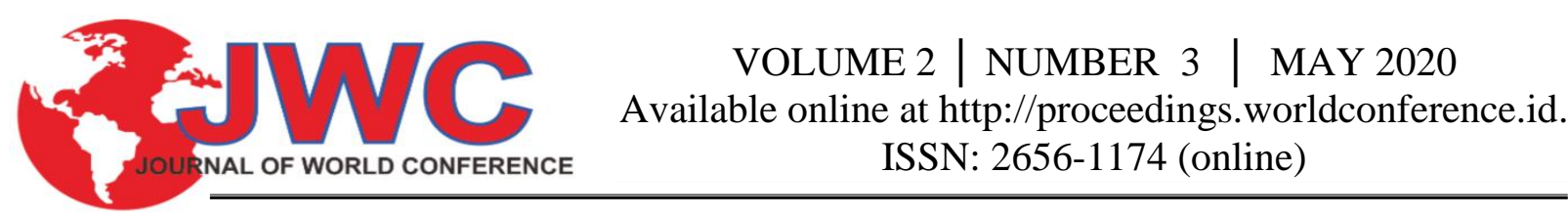

\subsection{Hypothesis testing \\ F Test (Simultaneous Test)}

Simultaneous test is used to determine whether all independent variables together have a significant influence on the dependent variable (Ghozali, 2013). By using the $\mathrm{F}$ test that is comparing the value of "F" "count" with the value of "F" "table". If the probability value $<0.05$ then the $F$ test can be used to predict the effect of the independent variable on the independent variable simultaneously. The significance of this influence can be estimated as the dependent variable criteria.

1 If "F" _ "count"> "F" "table" then the independent variable simultaneously influences the dependent variable.

2 If "F" - "count" <"F" "table" then the independent variable simultaneously has no effect on the dependent variable.

Table 4.19 Results of Calculation of Test F

ANOVA $^{\mathbf{b}}$
\begin{tabular}{|l|r|r|r|l|l|}
\hline Model & Sum of Squares & Df & Mean Square & F & Sig. \\
\hline 1 Regression & 95.466 & 3 & 31.822 & 44.653 & $.000^{a}$ \\
Residual & 46.877 & 36 & .710 & & \\
Total & 142.343 & 39 & & & \\
\hline
\end{tabular}

a. Predictors: (Constant), Total_X3, Total_X1,Total_X2

b. Dependent Variable: Total_Y

Source: SPSS Output Data (2019)

Based on Table 4.19 the results of the $\mathrm{F}$ test calculation obtained $\mathrm{F}$ count results 44.653 greater $\mathrm{F}$ table 2.262 with a sign level of 0.000 smaller $(\alpha) 0.05$, because the probability is smaller 0.05 then $\mathrm{H} 0$ is rejected and Ha is accepted. Thus the hypothesis which states that compensation, discipline and workload simultaneously have a significant positive effect on employee performance is empirically proven.

\section{T Test (Partial Test)}

Partial test is to find out whether the influence of each independent variable on the dependent variable is meaningful or not (Ghozali, 2013). probability $<0.05$ then the $t$ test can be used to partially predict the effect of the independent variable on the independent variable. The significance of this influence can be estimated by comparing between table values and calculated values.

1. If " $t$ " _ "count"> " $t$ " _ "table" then the independent variable partially influences the dependent variable and

2. If " $t$ " _ "count" <" $t$ " _ "table" then the independent variable partially has no effect on the dependent variable.

Table 4.20 Results of Test Calculations

Coefficients $^{\mathrm{a}}$

\begin{tabular}{|l|r|r|l|l|l|r|}
\hline & \multicolumn{2}{|l|}{ Unstandardized Coefficients } & Standardized Coefficients & & \\
\cline { 2 - 5 } Model & B & Std. Error & Beta & T & Sig. \\
\hline 1 (Constant) & .628 & 1.087 & & .578 & .565 \\
Total_X1 & .177 & .054 & & .262 & 3.278 & .002 \\
Total_X2 & .217 & .092 & & .247 & 2.353 & .022 \\
Total_X3 & .439 & .097 & .466 & 4.547 & .000 \\
\hline
\end{tabular}

a. Dependent Variable: Total_Y

Source: SPSS Output Data (2019)

Based on table 4.20 T Test partial hypothesis test results are obtained as follows: 


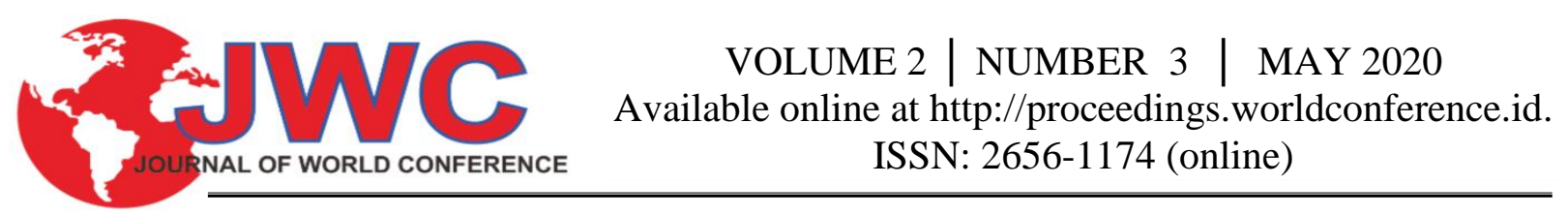

1. Effect of compensation variable (X1) on employee performance (Y) The results of the analysis of compensation variable (X1) obtained the value of " $\mathrm{t}$ " _ "count" of 3,278 and the value of " $\mathrm{t}$ " _ "table" of 2,028 with a significant value of 0.002 (smaller of 0.05 ) which is compensation artinvariable (X1) has a significant effect on employee performance (Y).

2. The influence of disciplinary variables (X2) on employee performance (Y) The results of disciplinary analysis (X2) obtained the value of " $\mathrm{t}$ " _ "count" of 4,547 and the value of " $\mathrm{t}$ " _ "table" of 2,028 with a significant value of 0.022 (smaller of 0.05 ) which means that the discipline variable (X2) has a significant effect on employee performance (Y).

3. Effect of workload variable (X3) on employee performance (Y) The results of workload variable analysis (X3) obtained the value of " $\mathrm{t}$ " _ "count" of 2,353 and the value of " $\mathrm{t}$ " _ "table" of 2,028 with a significant value of 0,000 (smaller than 0.05) which means that the workload variable (X3) has a significant effect on employee performance $(\mathrm{Y})$

\subsection{Classic assumption test Heteroscedasticity Test}

A regression is said to detect heteroscedasticity if the residual scatter diagram forms a certain pattern. if the residual scatter diagram output does not form a particular pattern, then the regression is free from heteroscedasticity cases and meets the requirements of classic assumptions about heteroskesdastisitas (Bilondatu, 2013). Graphs of Heteroscedactivity testing can be explained in the following figure:

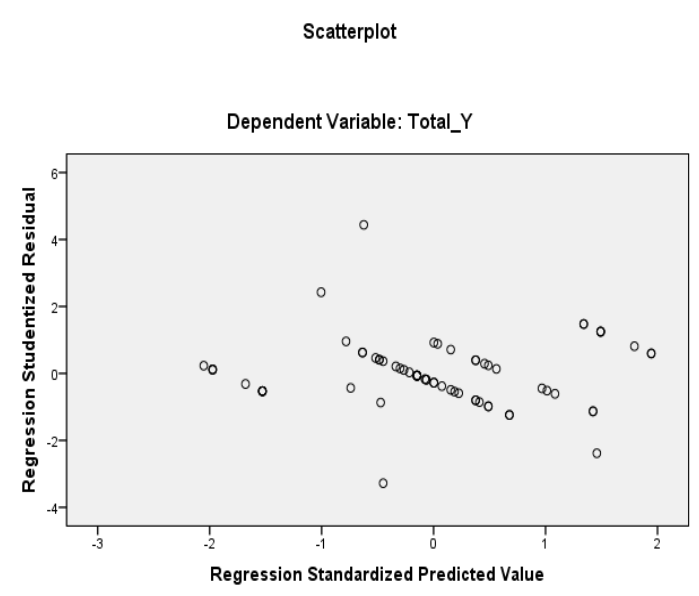

Figure 4.4: Heteroscedasticity Test Results

Source: SPSS Output Data (2019)

Based on the graph above it can be seen that the distribution of data is irregular and does not form certain patterns, and is spread above and below the number 0 on the $\mathrm{Y}$ axis, so it can be concluded that in this regression model heteroscedasticity problems do not occur.

\section{Multicollinearity Test}

Multicollinearity test aims to test whether the regression model found a correlation between independent variables (independent). Tolerance value calculation results show there are no independent variables that have a Tolerance value of less than 0.10 which means there is no correlation between the independent variables whose value is more than 95. The calculation results of the Variance Inflation Factor (VIF) value also indicate the same thing there is no single independent variable that has a VIF value of more than 10 . It can be concluded that there is no multicollinearity between the independent variables in the regression model (Bilondatu, 2013).

The multicollinearity test in this study can be seen as follows. 


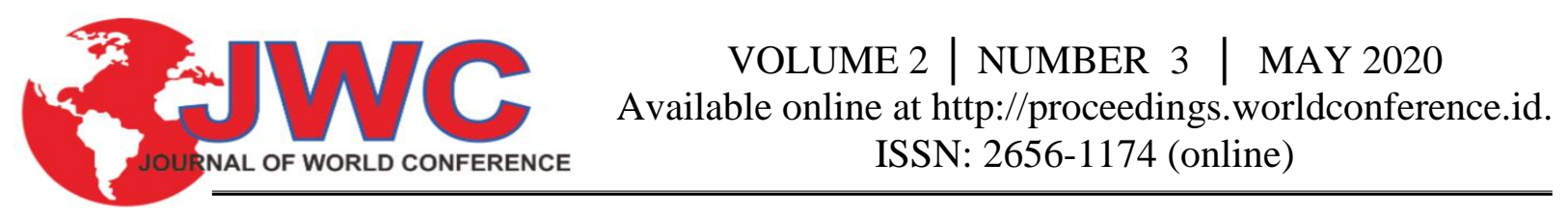

\section{Coefficients $^{\mathrm{a}}$}

Table 4.21 Multicollinearity Test

\begin{tabular}{|l|l|l|}
\hline \multirow{2}{*}{ Model } & \multicolumn{2}{|l|}{ Collinearity Statistics } \\
\cline { 2 - 3 } & Tolerance & \multicolumn{2}{l|}{ VIF } \\
\hline 1 (Constant) & .949 & 1.054 \\
Total_X1 & .979 & 1.021 \\
Total_X2 & .953 & 1.050 \\
Total_X3 & & \\
\hline
\end{tabular}

a. Dependent Variable: Total_Y

Source: SPSS Output Data (2019)

Based on Table 4.21 it can be seen that the regression model does not experience multicollinearity disorders. This can be seen in the tolerance value of each independent variable greater than 0.1. VIF calculation results also show that the VIF value of each independent variable is less than 10. So it can be concluded that there is no multicollinearity between independent variables in the regression model.

\section{Normality test}

Normality test is intended to find out whether the residuals under study are normally distributed or not. This test is used to $=$ determine whether a regression model, independent variables, dependent variables, or both have normal distribution or not.

In this test using a graphical approach, namely the standard P-P Normal Plot of regresion graph, with this test required that the distribution of research data must follow a diagonal line between 0 and the meeting of the $\mathrm{X}$ and $\mathrm{Y}$ axis.

The graph is presented in Figure 4 below:

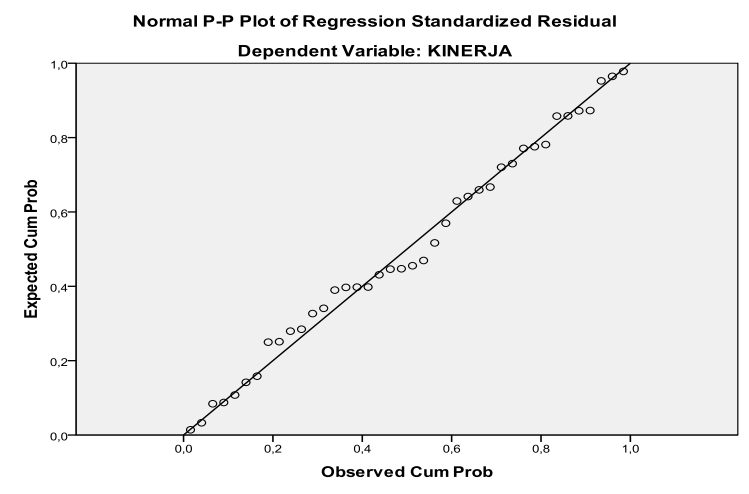

Figure 4.5 Normality Test Calculation Results

Source: SPSS Output Data (2019)

Based on the graph above shows that all existing data are normally distributed, because all data spread in a diagonal straight line then the data meets the normal assumption or follows the normality line.

\subsection{Discussion}

\section{Effect of Discipline on Employee Performance} performance.

Partially shows that there is a positive and significant influence on the variable of discipline on employee

Discipline is closely related to employee performance, the better the level of discipline, the greater the level of performance obtained. vice versa if the decline in work discipline will affect the small level of performance obtained. 


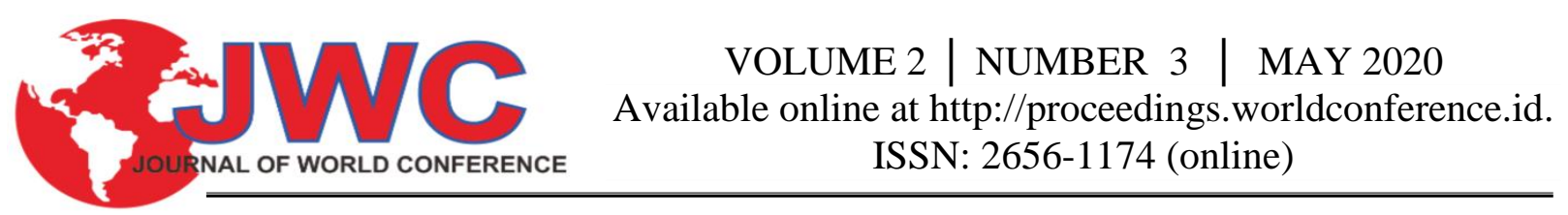

\section{Effect of Compensation on Employee Performance} performance.

Partially shows that there is a positive and significant effect on the compensation variable on employee

Compensation provided by the company to employees is certainly closely related to the employee's performance. If the compensation given matches the level of performance provided by employees for the company, it will emphasize the quality of the company

\section{Effect of Workloads on Employee Performance}

Partially shows a positive and significant effect on the variable workload on employee performance. This means that the smaller workload provided by the company is believed to have an effect on the better performance of employees who are run.

\section{Expenses Influence Dominant Against Employee Performance}

The results of testing the standardized beta coefficients value of the Customer's Values variable is 0.466 which is greater than the standardized coefficients of the Beta variables of the Discipline of 0 , 262, and Compensation of 0.247 .

Good performance will be formed if the overall assessment by employees of the discipline, compensation and workload provided by the company in accordance with applicable SOP standards.

\section{Effect of Discipline, Compensation, and Workload on Employee Performance}

$\mathrm{F}$ test results show that the simultaneous effect of all independent variables (Discipline, Compensation, and Workload) on employee performance. This is indicated from the magnitude of the F-count value of 44,653> F-table 2,262 with a significance level of 0,000 (less than 0.05 ).

Based on this research, Discipline, Compensation, Workload and Performance Karayawan has an important role on employee performance and refers to the company SOP which will affect the level of employee satisfaction with the company it self.

\section{Conclussion}

The conclusions of this study are:

1. Partially the independent variable of discipline (X1) employees significantly influence the performance of employees of PT. Tozy Sentosa Surabaya.

2. Partially the independent variable compensation (X2) significantly influence the performance of employees of PT. Tozy Sentosa Surabaya

3. Partially the independent workload variable (X3) has a significant effect on the performance of the employees of PT. Tozy Sentosa Surabaya.

4. Simultaneously the three independent variables X1 discipline, X2 compensation and X3 workload have a positive effect on the performance of employees of PT. Tozy Sentosa Surabaya.

5. From the determination test results obtained the coefficient of determination or Adjust R Square ("R" ^ "2") obtained for, 868 which means that the contribution of independent variables greatly influences the dependent variables of discipline (X1), compensation (X2), and workload (X3) on the dependent variable of employee performance $(\mathrm{Y})$ of $86.8 \%$ and for the remaining $13.2 \%$ influenced by variables not examined in the study.

Suggestions from this research are:

1. For the staff of PT. Tozy Sentosa Surabaya to pay attention to the quality of discipline on employee performance.

2. To improve employee performance, it needs to change the way work patterns in PT. Tozy Sentosa Surabaya to be even better.

3. Parastaff should pay more attention to the impressions conveyed by SPG (Sales Promotion Girl) who are at the forefront of selling products at PT. Tozy Sentosa Surabaya.

4. The next researcher is expected to develop this research with variables that have not been examined in this study such as product quality and price

\section{References}

Menurut Yuli (2005: 15) dalam Bintoro dan Daryanto (2017:16) sumber daya manusia Vol.5, No. 1, Oktober 2017

Menurut Bernandidan Russell (2001) dalam Bintoro dan Daryanto (2017:105) kinerja adalah catatan yang dihasilkan dari fungsi suatu pekerjaan

Menurut Rivai (2010:767) insentif sebagai bentuk pembayaran

Menurut Yuli (2005: 15) dalam Bintoro dan Daryanto (2017:16) sumber daya manusia Vol.5, No. 1, Oktober 2017 


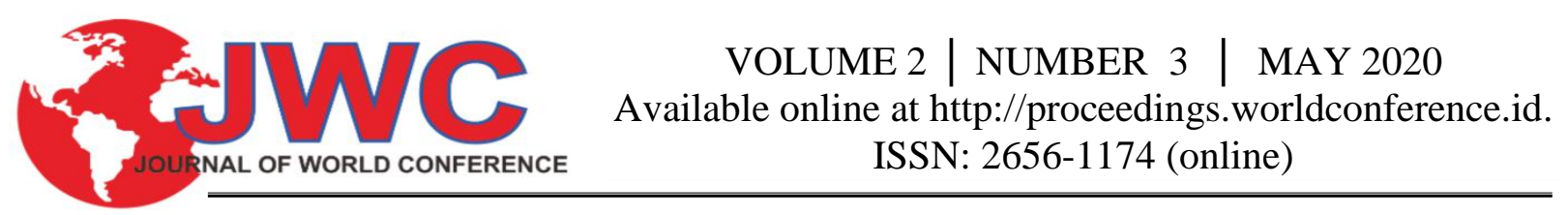

Menurut Bernandidan Russell (2001) dalam Bintoro dan Daryanto (2017:105) kinerja adalah catatan yang dihasilkan dari fungsi suatu pekerjaan

Menurut Rivai (2010:767) insentif sebagai bentuk pembayaran

Maddiansyah, A., \& Wahyudi. (2017). Pengaruh Kompensasi, Displin Kerja, dan Lingkungan Kerja Terhadap Kinerja Dosen Universitas Swasta di Wilayah Kopertis IV Provinsi Banten. Jurnal Kreatif: Pemasaran, Sumber Daya Manusia Dan Keuangan, 5(1), 30-44.

Heryati, A. (2016). Pengaruh Kompensasi Dan Beban Kerja Terhadap Loyalitas Karyawan Di Departemen Operasi Pt. Pupuk Sriwidjaja Palembang. Jurnal Ecoment Global, 1(2). https://doi.org/10.35908/jeg.v1i2.204

Paramitadewi, K. F. (2017). Pengaruh beban kerja dan kompensasi terhadap kinerja pegawai Sekretariat Pemerintah Daerah Kabupaten Tabanan. Jurnal Manajemen, 6(6), 3370-3397. Retrieved from https://www.google.com/url?sa=t\&rct=j\&q=\&esrc=s\&source=web\&cd=1\&cad=rja\&uact=8\&ved=2ahUKEwi W8_SxydzjAhVDfX0KHZM2AIMQFjAAegQIABAC\&url=https\%3A\%2F\%2Fojs.unud.ac.id\%2Findex.php\% 2FManajemen\%2Farticle\%2Fview\%2F29949\%2F18950\&usg=AOvVaw1OqdPDjAGV61VCB80O3Nc7

Ekonomi, F., \& Manajemen, J. (2019). Pengaruh Kompensasi Dan Disiplin Kerja Terhadap Kinerja Karyawan Di Yuta Hotel Manado. Jurnal EMBA: Jurnal Riset Ekonomi, Manajemen, Bisnis Dan Akuntansi, 7(1).

Armansyah, A., Azis, I., \& Rossanty, N. P. evvy. (2018). Pengaruh kompensasi dan disiplin kerja terhadap kinerja pegawai kantor bpjs kesehatan cabang palu. Ilmu Manajeman Universitas Tadulako, 4(3), 235-244.

Thaief, I., Baharuddin, A., Priyono, \& Idrus, M. S. (2015). Effect of training, compensation and work discipline against employee job performance: (Studies in the office of PT. PLN (Persero) Service Area and Network Malang). Review of European Studies, 7(11), 23-33. https://doi.org/10.5539/res.v7n11p23

Tulangow, M. J., Saerang, D. P. E., \& Rumokoy, F. S. (2015). The Effect of Job Stress, Workload and Work Environment on Employee Turnover (Case Study At Pt Hasjrat Abadi Manado). Jurnal Berkala Ilmiah Efisiensi, $15(05), 851-861$.

Setiadi, R. U., \& Setiadi, P. B. (2016). The effect of compensation and work motivation on employee performance at semen indonesia limited company. International Journal of Academic Research and Reflection, 4(3), 64-85.

Simatupang, A. C., \& P, P. S. (2018). The Effect of Discipline, Motivation and Commitment to Employee Performance. IOSR Journal of Business and Management, 20(6), 31-37. https://doi.org/10.9790/487X2006013137

Lumintang, G., Adolfina, A., \& Muhammad, S. (2016). Pengaruh Lingkungan Kerja, Kompensasi Dan Beban Kerja Terhadap Kinerja Karyawan Pada Dinas Pendapatan Daerah Kota Manado. Jurnal Riset Ekonomi, Manajemen, Bisnis Dan Akuntansi, 4(1), 45-55.

Hasibuan, SP Malayu. 2003. Manajemen Sumber Daya Manusia. Jakarta. Bumi Aksara.

2007. Manajemen Sumber Daya Manusia. .dJakarta. Bumi Aksara.

Handoko T. Hani. 2000. Manajemen Personalia dan Sumber Daya Manusia.

Edisi Kedua. Yogyakarta: BPFE.

HaniHandoko (2000:155) menyatakan bahwa: kompensasi adalah segala sesuatu yangditerima oleh pegawai sebagai balas jasa

Sulistiyani, A.T. dan Rosidah. 2003.Manajemen Sumber Daya Manusia, Konsep, Teoridan Pengembangandalam Konteks Organisasi Publik. Yogyakarta: Graha Ilmu

Siswanto Sastrohadiwiryo. 2003,Manajemen Tenaga KerjaIndonesia. Jakarta: PT BumiAksara

Natoatmodjo, Soekidjo. 2012. Pengembangan Sumber Daya Manusia. Rineka Cipta Jakarta.

Robbins, Stephen P. 2006. Perilaku Organisasi. Jakarta. Index.

Schultz, D., Schultz, S E. 2006. Psycology\& Work Today (Ninth Edition). NewJersey : Pearson Education. Inc.

Robbins, Stephen P. 2011. Perilaku Organisasi. Jakarta. Index.dan Mery Coulter. 2012. Perilaku Organisasi. Edisi 12. Alih Bahasa Diana Angelica,

Mangkunegara, A. A. Anwar Prabu. 2000. Manajemen Sumber Daya Manusia Perusahaan.Bandung. Remaja Rosdakarya.

Sugiyono. (2013). MetodePenelitian Kuantitatif, Kualitatif dann R\&D. Bandung: PT. Alfabet.

Sutrisno, E. 2009. Manajemen Sumber Daya Manusia Edisi pertama. Kencana Prenada Media Group, Jakarta.

Mangkunegara. A. A. Anwar Prabu, 2011. Perilaku Konsumen. Cetakan I. PT. Eresco Bandung, 1998.

Mangkunegara. A. A. Anwar Prabu, 2011. Manajemen Sumber Daya Manusia Perusahaan. Bandung:PT Remaja Rosdakarya

Hasibuan, S.P. Malayu. 2009. ManajemenSumber Daya Manusia, cetakanketujuh. Jakarta : PT Bumi Aksara.

Hasibuan, S.P. Malayu. 2010. ManajemenSumber Daya Manusia, edisi revisi.Jakarta : PT Bumi Aksara.

Ghozali. 2012. Aplikasi Analisis Multivariate Dengan Program SPSS. Edisi Keempat. Penerbit UniversitasDiponegoro, Semarang. 
Ghozali. 2013. Aplikasi Analisis Multivariate Dengan Program SPSS. Edisi Keempat. Penerbit UniversitasDiponegoro, Semarang.

Yuliana. (2015). Pengaruh Kompetensi dann Motivasi Keeerja terhadap Kinerja Karyawan Perusahaan padaa PT. Haluan Star Logistic. Jurnal Ilmiah Manajemen Bisnis, 17(2), 135-150.

(Arikunto, 2008: 72) ManajemenSumber Daya Manusia, cetakanketujuh. Jakarta

(Sugiyono, 2013) ). MetodePenelitian Kuantitatif, Kualitatif dann R\&D. Bandung: PT. Alfabet.

(Ghozali, 2013) Aplikasi Analisis Multivariate Dengan Program SPSS. Edisi Keempat. Penerbit UniversitasDiponegoro, Semarang.

(Bilondatu, 2013) . Pengembangan Sumber Daya Manusia. Rineka Cipta Jakarta 